\title{
PENGARUH MODEL PEMBELAJARAN BERBASIS MASALAH DAN MOTIVASI BERPRESTASI TERHADAP HASIL BELAJAR IPA SISWA KELAS IX SMP NEGERI 1 KUBU
}

\author{
Ni Ketut Suriani' ${ }^{1}$ I Wayan Santyasa ${ }^{2}$, Ni Nyoman Parwati ${ }^{3}$ \\ 1, 2, 3 Program Studi Teknologi Pembelajaran, Program Pascasarjana \\ Universitas Pendidikan Ganesha \\ Singaraja, Indonesia \\ e-mail: (ketut.suriani, wayan.santyasa)@pasca.undiksha.ac.id, \\ parwatimat@gmail.com
}

\begin{abstract}
Abstrak
Penelitian ini bertujuan mendeskripsikan pengaruh model pembelajaran berbasis masalah dan motivasi berprestasi terhadap hasil belajar IPA. Penelitian ini merupakan penelitian eksperimen semu dengan menggunakan rancangan Anacova dua jalan. Populasi penelitian adalah siswa kelas IX SMP Negeri 1 Kubu Tahun Pelajaran 2016/2017 sebanyak 286 orang. Teknik Group Random sampling digunakan untuk menetapkan 4 kelas sebagai sampel, kemudian dirandom kembali untuk menentukan 2 kelas sebagai kelompok eksperiman 2 kelas yang lain sebagai kelompok kontrol. Data motivasi berprestasi dikumpulkan dengan angket, sedangkan data hasil belajar IPA dikumpulkan dengan tes. Data penelitian dianalisis dengan menggunakan uji statistik Anakova dua jalan Hasil penelitian menunjukkan bahwa, (1) Setelah perlakuan dikontrol dengan kovariabel hasil belajar awal terdapat perbedaan hasil belajar antara siswa yang belajar dengan model pembelajaran berbasis masalah dan siswa yang mengikuti model pembelajaran konvensional. Skor hasil belajar yang diperoleh oleh siswa yang mengikuti model pembelajaran berbasis masalah lebih tinggi dibandingkan dengan siswa yang mengikuti model pembelajaran konvensional, (2) Setelah perlakuan dikontrol dengan kovariabel hasil belajar awal terdapat perbedaan hasil belajar IPA antara siswa yang memiliki motivasi berprestasi tinggi dengan siswa yang memiliki motivasi berprestasi rendah. Hasil belajar siswa yang memiliki motivasi berprestasi tinggi lebih baik dibandingkan dengan siswa yang memiliki motivasi berprestasi rendah, (3) Setelah perlakuan dikontrol dengan kovariabel hasil belajar awal terdapat pengaruh interaktif antara model pembelajaran dan motivasi berprestasi terhadap hasil belajar IPA.
\end{abstract}

Kata kunci: model pembelajaran berbasis masalah, motivasi berprestasi, dan hasil belajar IPA

\begin{abstract}
This research aimed at describing the effect of problem based learning model and achievement motivation on the students' achievement science. This is a quasi-experimental research with two way anacova designed. The population in this study were the IX grade of SMP Negeri 1 Kubu in the academic year of 2016/2017 consisting of 286 students. The selection of the samples for this study were based on group random sampling technique, four classes were selected as random, two classes as the experimental group and the others are the control group. The data of learning achievement motivation were collected by questionnaire while the data of students' achievement in science were collected by achievement test. The data obtained then were analyzed by using Anacova statistic two way anacova. The results of this study were: (1) after treatment was controlled by prior achievement of students as covariable there was a significant difference of students' achievement in scince between the students learn in the guided problem based learning model and conventional model.Students' achievent which learned in the problem based learning model model was higher than them in conventional model, (2) after treatment was controlled by prior achievement of students as covariable there was a significant difference of the students' achievement in science between students with high Achievement Motivation and the students with low achievement motivation. Students' achievent which had high achievement motivation
\end{abstract}


was higher than them low achievement motivation, (3) after treatment was controlled by prior achievement of students as covariable there was interaction effect between the learning model and the achievement motivation on the students' achievement in science.

Keywords: problem based learning model, achievement motivation, and science achievement result students.

\section{PENDAHULUAN}

Pendidikan merupakan salah satu usaha dalam meningkatkan kualitas dan potensi yang dimiliki oleh setiap individu. Pelaksanaan pendidikan hendaknya tidak semata-mata untuk memperoleh hasil, tetapi proses belajar yang dialami oleh siswa juga menjadi fokus perhatian dari guru sebagai pendidik. Pelaksanaan pendidikan harus mampu menyediakan kesempatan seluas-luasnya bagi siswa sebagai pusat pembelajaran untuk memperoleh bekal pengetahuan, keterampilan, dan nilai-nilai. Untuk mewujudkan hal tersebut, maka pelaksanaan pendidikan harus dilakukan secara bermakna (meaningful learning). Sekolah sebagai salah satu penyelenggara pendidikan diharapkan mampu berperan untuk mewujudkan tujuan tersebut. Sekolah selayaknya menunjukkan perannya sebagai pusat pembelajaran bagi peserta didik, memberikan fasilitas, pelayanan bagi terwujudnya sumber daya manusia yang mandiri, mampu bersaing secara nasional maupun internasional.

IPA termasuk salah satu pelajaran yang memiliki karakteristik sangat kompleks. IPA berkaitan dengan cara mencari tahu tentang alam secara sistematis, sehingga IPA bukan hanya penguasaan kumpulan pengetahuan yang berupa fakta-fakta, konsep-konsep, atau prinsip-prinsip saja tetapi juga merupakan suatu proses penemuan. Pendidikan IPA diharapkan dapat menjadi wahana bagi peserta didik untuk mempelajari diri sendiri dan alam sekitar, serta prospek pengembangan lebih lanjut dalam menerapkannya di dalam kehidupan seharihari. Proses pembelajarannya menekankan pada pemberian pengalaman konvensional untuk mengembangkan kompetensi agar menjelajahi dan memahami alam sekitar secara ilmiah. Pendidikan IPA diarahkan untuk inkuiri dan berbuat sehingga dapat membantu peserta didik untuk memperoleh pemahaman yang lebih mendalam tentang alam sekitar. Melalui pembelajaran IPA, peserta didik dapat memperoleh pengalaman konvensional, sehingga dapat menambah kekuatan untuk menerima, menyimpan, dan menerapkan konsep yang telah dipelajarinya. Dengan demikian, peserta didik terlatih untuk dapat menemukan sendiri berbagai konsep yang dipelajari secara menyeluruh (holistik), bermakna, autentik, dan aktif (Permendikbud No 58 Tahun 2014).

Kenyataan yang kita temukan di lapangan sekolah yang menerapkan pembelajaran IPA dalam proses pembelajarannya masih minim dalam menerapkan pembelajaran berbasis penyikapan/ penelitian atau pembelajaran yang menghasilkan karya berbasis masalah. Proses pembelajarannya hanya menggunakan pendekatan saintifik semata tanpa penguatan dengan melibatkan model pembelajaran, hal ini terlihat dari rancangan RPP yang disusun oleh guru. Diawal proses pembelajaran khususnya pada kegiatan mengamati, guru jarang menyajikan informasi yang menarik keingintahuan siswa pada materi yang dipelajari. Informasi menarik pada kegiatan mengamati dapat berupa masalah nyata yang ditemui siswa dalam kehidupannya sehari-hari.

Berpedoman pada hal di atas, guru sebaiknya menerapkan model pembelajaran yang inovatif yang dapat membantu siswa mengembangkan kemampuannya dalam memecahkan masalah belajar. Model pembelajaran yang memungkinkan dikembangkannya keterampilan berpikir siswa dalam memecahkan masalah adalah dengan model Problem Based Learning (PBL), dalam penelitian ini peneliti menggunakan istilah pembelajaran berbasis masalah.

$$
\text { Wiratmaja et al. }
$$
pembelajaran berbasis masalah 
memberikan tantangan kepada siswa untuk belajar sendiri. Dalam pembelajaran berbasis masalah, siswa lebih diajak untuk membentuk suatu pengetahuan dengan sedikit bimbingan atau arahan guru. Dengan demikian pebelajar diberi kesempatan untuk berperan secara aktif dan konstruktif dalam memonitor dan mengontrol motivasi, kognisi dan tingkah laku untuk mencapai tujuan pembelajaran yang telah dirumuskan.

Mengetahui tujuan dari apa yang dipelajari siswa merupakan faktor penting dalam proses pembelajaran, karena hal tersebut akan mampu membangkitkan keinginan yang lebih kuat dari dalam diri siswa untuk belajar. Dorongan yang dapat menimbulkan perilaku tertentu yang mengarah kepada pencapaian tujuan ini disebut sebagai motivasi (Sanjaya 2009). Motivasi merupakan salah satu aspek psikologis yang mendorong individu untuk memilih, melaksanakan, dan mengarahkan aktivitasnya. Semakin kuat motivasi seseorang semakin besar kemungkinannya sukses untuk melaksanakan tugas atau kegiatannya. Motivasi berprestasi merupakan dorongan yang ada pada diri seseorang untuk meraih yang terbaik dalam bidang tertentu, khususnya bidang akademik (Nuryanti, 2008). Dalam bidang akademik, motivasi berprestasi akan muncul dalam bentuk usaha untuk mendapatkan nilai yang baik, dapat mengatasi rintangan belajar, mempertahankan kualitas prestasi belajar yang baik dan bersaing dengan orang lain untuk menjadi yang terbaik.

$$
\text { Istilah motivasi berprestasi }
$$

merupakan perpaduan dari dua istilah "motivasi" dan "prestasi" yang membentuk suatu kesatuan makna dan intepretasi. Motivasi berprestasi merupakan faktor pendorong untuk meraih atau mencapai sesuatu yang diinginkannya untuk meraih kesuksesan. Untuk mencapai kesuksesan tersebut setiap orang mempunyai hambatan-hambatan yang berbeda dan dengan memiliki motivasi berprestasi tinggi diharapkan hambatan-hambatan tersebut akan dapat diatasi dan kesuksesan yang diinginkan dapat diraih (Innayah, 2013). bahwa sernyataan ini mengisyaratkan motivasi berprestasi siswa juga diduga berpengaruh terhadap hasil belajar IPA. Oleh karena itu, dalam penelitian ini dilibatkan motivasi berprestasi sebagai variabel moderator yang diduga berpengaruh terhadap hasil belajar IPA siswa.

Oleh karena itu, perlu penelitian terkait dengan aspek tersebut. Tujuan yang ingin dicapai melalui penelitian ini adalah untuk menjelaskan (1) Mendeskripsikan perbedaan hasil belajar IPA antara siswa yang belajar dengan model pembelajaran berbasis masalah dengan peserta didik yang belajar dengan pembelajaran konvensional setelah perlakuan dikontrol dengan kovariabel hasil belajar awal, (2) mendeskripsikan perbedaan hasil belajar IPA antara siswa yang memiliki motivasi berprestasi tinggi dengan siswa yang memiliki motivasi berprestasi rendah setelah perlakuan dikontrol dengan kovariabel hasil belajar awal, mendeskripsikan pengaruh interaktif antara model pembelajaran dan motivasi berprestasi terhadap hasil belajar siswa pada mata pelajaran IPA setelah perlakuan dikontrol dengan kovariabel hasil belajar awal.

\section{METODE}

Pendekatan dalam penelitian adalah pendekatan kuantitatif yang menekankan analisisnya pada data-data numerik dengan metode statistik. Penelitian adalah penelitian eksperimen yang bertujuan untuk mengetahui akibat dari suatu tindakan atau eksperimen dan membandingkan dengan kelompok control (dalam Candiasa, 2004). Sampel penelitian adalah siswa sehingga penelitian yang dilaksanakan adalah penelitian eksperimen kuasi (quasy experiment) mengingat tidak semua variable dan kondisi eksperimen dapat diatur dan dikendalikan atau dikontrol. Kelompok eksperimen dilaksanakan dengan menerapkan model pembelajaran berbasis masalah dan kelompok kontrol dengan menerapkan model pembelajaran konvensional. 
Rancangan penelitian mengikuti rancangan eksperimen pretest-posttest nonequivalent control group design seperti pada gambar berikut.

$\begin{array}{ccc}\mathrm{O}_{1} & \mathrm{X}_{1} & \mathrm{O}_{2} \\ \mathrm{O}_{3} & \mathrm{X}_{2} & \mathrm{O}_{4}\end{array}$

Gambar 1 Desain pretest - posttest nonequivalent control group

Rancangan analisisnya menggunakan rancangan Anakova 2 Jalan seperti pada Tabel 1.

Tabel 1.Rancangan Anakova 2 Jalan

\begin{tabular}{|c|c|c|}
\hline $\begin{array}{l}\text { Motivasi } \\
\text { Berprestasi }\end{array}$ & $\mathrm{A}_{1}$ & $\mathrm{~A}_{2}$ \\
\hline $\mathrm{B}_{1}$ & $\mathrm{~A}_{1} \mathrm{~B}_{1}$ & $\mathrm{~A}_{2} \mathrm{~B}_{1}$ \\
\hline $\mathrm{B}_{2}$ & $\mathrm{~A}_{1} \mathrm{~B}_{2}$ & $\mathrm{~A}_{2} \mathrm{~B}_{2}$ \\
\hline
\end{tabular}

Untuk meyakinkan bahwa hasil eksperimen benar-benar sebagai akibat perlakuan maka dilakukan dengan melaksanakan pretes dan postes serentak dan diawasi secara ketat, uji coba empirik terhadap instrumen penelitian, jumlah sampel tidak boleh berubah, dan kemampuan dan pengalaman guru yang melakukan eksperimen relatif sama.

Populasi dalam penelitian ini adalah kelas IX SMP Negeri 1 Kubu semester ganjil Tahun Pelajaran 2016/2017 . Siswa terbagi ke dalam tujuh kelas yang tersebar secara random. Sampel penelitian ditentukan dengan menggunakan teknik random dan terpilih empat kelas sebagai sampel yaitu kelas IXD, IXE, IXF, dan IXG. Kelas-kelas sampel ini diundi kembali untuk menentukan kelas eksperimen dan kelas kontrol. Dari hasil pengundian diperoleh kelas IXD dan IXE sebagai kelas eksperimen dengan proses pembelajarannya menggunakan model pembelajaran berbasis masalah dan kelas IXF dan IXG sebagai kelas kontrol serta dalam proses pembelajarannya menggunakan model pembelajaran konvensional.

Penelitian ini melibatkan tiga variabel, yaitu variabel bebas, moderator, dan terikat. Variabel bebas dalam penelitian adalah model pembelajaran dengan dua dimensi yaitu model pembelajaran berbasis masalah dan model pembelajaran konvensional, variabel moderator dalam penelitian adalah motivasi berprestasi dengan dua dimensi yaitu motivasi berprestasi tinggi dan motivasi berprestasi rendah. Variabel terikat dalam penelitian adalah hasil belajar IPA siswa.

Langkah-langkah yang ditempuh dalam penelitian ini terdiri dari tiga langkah, yaitu persiapan, pelaksanaan, dan pengakhiran eksperimen. Tahap persiapan eksperimen, langkah-langkah yang dilaksanakan adalah: (1) menyusun rencana pelaksanaan pembelajaran, media pembelajaran, dan lembar kerja siswa, (2) menyusun kelompok kerja siswa yang heterogen, (3) menyusun instrumen penelitian, kisi-kisi dan tes hasil belajar IPA, kisi-kisi dan kuesioner motivasi berprestasi, (4) mengkonsultasikan instrumen penelitian dengan dosen pembimbing dan ahli (judges), (5) uji coba tes hasil belajar IPA dan kuesioner motivasi berprestasi, (6) mengadakan validasi instrumen penelitian yaitu tes hasil belajar IPA dan kuesioner motivasi berprestasi. Pelaksanaan eksperimen pada tiap-tiap kelompok, baik kelompok eksperimen dan kontrol dilaksanakan sebanyak 8 kali, 1 kali pertemuan untuk melaksanakan pretes, 1 kali pertemuan untuk memberikan kuesioner motivasi berprestasi, 5 kali pertemuan untuk treatment (tindakan), dan 1 kali pertemuan untuk melaksanakan postes. Langkah-langkah yang dilaksanakan adalah sebagai berikut: (1)menentukan kelas sampel penelitian dari kelas populasi yang tersedia, (2) dari sampel yang telah diambil, diundi untuk menentukan kelas eksperimen dan kontrol, (3) memberikan kuesioner motivasi berprestasi kepada semua kelompok sampel untuk memilah siswa yang memiliki motivasi berprestasi tinggi dan motivasi berprestasi rendah, (4) melaksanakan penelitian dengan memberikan perlakuan kepada kelas eksperimen dengan model pembelajaran berbasis masalah dan memberikan perlakuan kepada kelas kontrol berupa pembelajaran konvensional. Tahap akhir eksperimen, langkah yang 
dilaksanakan adalah memberikan postes, baik pada kelompok eksperimen dan kelompok kontrol.

Data yang dikumpulkan dalam penelitian berupa data hasil belajar IPA melalui tes hasil belajar IPA berupa soal pilihan ganda dan data Motivasi berprestasi siswa melalui kuesioner motivasi berprestasi. Kedua instrumen penelitian divalidasi dengan tujuan item tes yang digunakan dapat dipercaya sebagai alat pengumpul data penelitian. Validitas isi (content validity) dilakukan oleh dosen ahli (expert judges). Kedua instrumen, baik tes hasil belajar IPA dan kuesioner motivasi berprestasi diuji konsistensi internal butir dan reliabilitas tes. Indeks daya beda dan indeks kesukaran butir hanya dilakukan pada tes hasil belajar IPA. Hasil uji coba kedua instrumen menunjukkan bahwa koefisien korelasi $r_{x y}>0,273$ yang berarti soal dapat digunakan. koefisien reliabiltas kedua instrumen $r_{x y} \geq 0,70$ yang berarti instrumen akurat dalam memberikan data sesuai kenyataan. Sedangkan dari indeks daya beda dan indeks kesukaran butir sudah sesuai dengan criteria penelitian yaitu IDB $>0,20$ dan $0,30 \geq \operatorname{IKB} \geq 0,70$.

Analisis data deskriptif untuk mengetahui pola sejumlah data penelitian, merangkum informasi yang terdapat dalam data penelitian, dan menyajikan informasi tersebut dalam bentuk yang diinginkan. Sebelum dianalisis, terlebih dahulu dilakukan uji normalitas, uji homogenitas, dan uji linieritas sebagai uji prasyarat uji hipotesis penelitian. Teknik analisis data yang digunakan untuk menguji hipotesis penelitian adalah analisis Anakova dua jalan. Kriteria yang digunakan, tolak $\mathrm{H}_{0}$ jika angka signifikan yang dihasilkan lebih kecil dari 0,05 .

\section{HASIL DAN PEMBAHASAN}

Penelitian ini pada dasarnya dilaksanakan untuk mengetahui ada tidaknya perbedaan hasil belajar IPA siswa sebagai hasil perlakuan antara penerapan model pembelajaran berbasis masalah dan pembelajaran konvensional sebagai kontrolnya dan mempertimbangkan motivasi berprestasi.
Penelitian ini menggunakan desain Anakova dua jalan dengan empat sel perlakuan. Pada masing-masing sel perlakuan untuk kelas eksperimen dan kontrol ditetapkan masing-masing memiliki 26 subjek analisis, sehingga jumlah subjek secara keseluruhan adalah 104 subjek. Adapun keempat kelompok data tersebut adalah: (1) data hasil belajar IPA siswa yang mengikuti model pembelajaran berbasis masalah, (2) data hasil belajar IPA siswa yang mengikuti model pembelajaran konvensional, (3) data hasil belajar IPA siswa yang memiliki motivasi berprestasi tinggi, (4) data hasil belajar IPA siswa yang memiliki motivasi berprestasi rendah.

Deskripsi data yang berkaitan dengan ukuran sentral seperti rataan hitung, modus, median, dan ukuran penyebaran data (standar deviasi) untuk semua data tersebut dapat dilihat pada Tabel 2.

Tabel 2. Rekapitulasi Hasil Perhitungan Hasil belajar IPA Siswa

\begin{tabular}{|l|c|c|c|c|}
\hline \multicolumn{1}{|c|}{$\begin{array}{c}\text { Sta- } \\
\text { tistik }\end{array}$} & $\begin{array}{c}\mathbf{A}_{\mathbf{1}} \\
\mathbf{( N = 5 2 )}\end{array}$ & $\begin{array}{c}\mathbf{A}_{\mathbf{2}} \\
\mathbf{( N = 5 2 )}\end{array}$ & $\begin{array}{c}\mathbf{B}_{\mathbf{1}} \\
\mathbf{( N = 5 2 )}\end{array}$ & $\begin{array}{c}\mathbf{B}_{\mathbf{2}} \\
\mathbf{( N = 5 2 )}\end{array}$ \\
\hline Mean & 78,01 & 69,87 & 79,62 & 68,27 \\
\hline Median & 76,67 & 70,00 & 80,00 & 70,00 \\
\hline $\begin{array}{l}\text { Std. } \\
\text { Deviation }\end{array}$ & 7,73 & 6,73 & 6,39 & 5,70 \\
\hline Variance & 59,81 & 45,30 & 40,81 & 32,46 \\
\hline Range & 30 & 27 & 23 & 20 \\
\hline Min & 63 & 57 & 70 & 57 \\
\hline Max & 93 & 83 & 93 & 77 \\
\hline
\end{tabular}

Pengujian terhadap hipotesis penelitian dilakukan dengan menggunakan formula statistik Anakova dua jalan yang kemudian dilanjutkan dengan uji Tukey jika hasil akhir menunjukkan hasil yang signifikan. Sebelum melakukan uji hipotesis dengan menggunakan formula statistik Anakova dua jalan, maka terlebih dahulu harus dilakukan uji prasyarat analisis yang meliputi uji normalitas sebaran data, uji homogenitas varians dan linieritas.

Uji normalitas sebaran data yang dilakukan dalam penelitian ini adalah teknik Kolmogorov Smirnov dan Shapiro-Wilk test dengan bantuan Program SPSS 16.0 for Windows (Candiasa, 2004). Uji normalitas sangat perlu dilakukan untuk meyakinkan bahwa uji statistik yang digunakan dalam pengujian hipotesis benar-benar dapat dilakukan. Hasil perhitungan dengan teknik Kolmogorov Smirnov dan Shapiro-Wilk test 
menunjukkan nilai sig $>0,05$, hasil ini membuktikan data hasil belajar IPA untuk keempat kelompok data tersebut berasal dari populasi yang berdistribusi normal.

Uji homogenitas yang dilakukan dalam penelitian ini menggunakan uji Levene's test of equality of error variance dengan SPSS 16.0 for Windows (Candiasa, 2004). Uji homogenitas dilakukan untuk meyakinkan bahwa perbedaan yang diperoleh dari uji Anakova dua jalan, benarbenar berasal dari perbedaan antar kelompok, bukan disebabkan oleh perbedaan di dalam kelompok. Hasil uji homogenitas menunjukkan taraf signifikansi 0,142 . Jika ditetapkan taraf signifikansi 0.05 , maka hasil signifikansi perhitungan $0,142>0,05$, dan disimpulkan bahwa semua kelompok data memiliki varians yang homogen.

Uji linieritas menunjukkan nilai $F$ deviation from linearity besarnya 1,932 dengan nilai signifikansinya 0,083 . Nilai sig dari $F$ deviation from linearity menunjukkan lebih besar dari nilai signifikansi yang ditetapkan sehingga hipotesis nol diterima dan hipotesis alternatif ditolak. Hal ini berarti bahwa bentuk regresinya adalah linier.

Uji hipotesis dalam penelitian dilakukan dengan menggunakan formula Anakova dua jalan. Selanjutnya apabila diketahui terdapat interaksi antara model pembelajaran dengan motivasi berprestasi dalam pengaruhnya terhadap hasil belajar IPA dapat dilanjutkan dengan uji Tukey. Uji Tukey bertujuan untuk menentukan kelompok mana yang lebih unggul. Hasil perhitungan dengan Anakova dua jalan dapat dilihat dalam Tabel 3.

Tabel 3 Ringkasan Hasil Perhitungan Anakova Dua Jalan

\begin{tabular}{|l|r|r|r|r|c|}
\hline Source & $\begin{array}{r}\text { Type III } \\
\text { Sum of } \\
\text { Squares }\end{array}$ & df & $\begin{array}{r}\text { Mean } \\
\text { Squar } \\
\text { e }\end{array}$ & F & Sig. \\
\hline $\begin{array}{l}\text { Corrected } \\
\text { Model }\end{array}$ & $\begin{array}{r}1779,79 \\
6\end{array}$ & 4 & $\begin{array}{r}444,94 \\
9\end{array}$ & $\begin{array}{r}14,6 \\
64\end{array}$ & 0,000 \\
\hline Intercept & $\begin{array}{r}7959,58 \\
7\end{array}$ & 1 & $\begin{array}{r}7959,5 \\
87\end{array}$ & $\begin{array}{r}262, \\
312\end{array}$ & 0,000 \\
\hline Kovariat & 49,719 & 1 & 49,719 & $\begin{array}{r}1,63 \\
9\end{array}$ & 0,204 \\
\hline MP & 272,844 & 1 & 272,84 & 8,99 & 0,003 \\
\hline
\end{tabular}

\begin{tabular}{|l|c|c|r|r|c|}
\hline Source & $\begin{array}{c}\text { Type III } \\
\text { Sum of } \\
\text { Squares }\end{array}$ & df & $\begin{array}{c}\text { Mean } \\
\text { Squar } \\
\text { e }\end{array}$ & F & Sig. \\
\hline & & & 4 & 2 & \\
\hline $\mathrm{MB}$ & 782,764 & 1 & $\begin{array}{r}782,76 \\
4\end{array}$ & $\begin{array}{r}25,7 \\
96\end{array}$ & 0,000 \\
\hline $\mathrm{MP}{ }^{*} \mathrm{MB}$ & 361,753 & 1 & $\begin{array}{r}361,75 \\
3\end{array}$ & $\begin{array}{r}11,9 \\
22\end{array}$ & 0,001 \\
\hline
\end{tabular}

Tabel 4 Ringkasan Hasil Uji Tukey

\begin{tabular}{|c|c|c|}
\hline \multirow{2}{*}{ (I) MP } & $\begin{array}{c}\text { (J) Model } \\
\text { Pembelajaran }\end{array}$ & $\begin{array}{c}\text { Mean } \\
\text { Difference } \\
\text { (I-J) }\end{array}$ \\
\hline \multirow{3}{*}{ PBM MB Tinggi } & PBM MB Rendah & 2,50 \\
\cline { 2 - 3 } & MPK MB Tinggi & 0,54 \\
\cline { 2 - 3 } & MPK MB Rendah & $8,50^{*}$ \\
\hline \multirow{3}{*}{ PBM MB Rendah } & PBM MB Tinggi & $-2,50$ \\
\cline { 2 - 3 } & MPK MB Tinggi & $-1,96$ \\
\cline { 2 - 3 } & MPK MB Rendah & $6,00^{*}$ \\
\hline \multirow{3}{*}{ MPK MB Tinggi } & PBM MB Tinggi &,- 54 \\
\cline { 2 - 3 } & PBM MB Rendah & 1,96 \\
\cline { 2 - 3 } & MPK MB Rendah & $7,96^{*}$ \\
\hline \multirow{3}{*}{ MPK MB Rendah } & PBM MB Tinggi & $-8,50^{*}$ \\
\cline { 2 - 3 } & PBM MB Rendah & $-6,00^{*}$ \\
\cline { 2 - 3 } & MPK MB Tinggi & $-7,96^{*}$ \\
\hline
\end{tabular}

Perbedaan hasil belajar IPA antara kelompok siswa yang belajar dengan model pembelajaran berbasis masalah dan kelompok siswa yang belajar dengan model pembelajaran Ikonvensional, berdasarkan hasil penghitungan Anakova dua jalan , diperoleh sig. 0,003, ini berarti $\mathrm{H}_{0}$ ditolak dan $\mathrm{H}_{1}$ diterima, yaitu hasil belajar IPA siswa yang mengikuti pembelajaran berbasis masalah tidak sama dengan hasil belajar IPA siswa yang mengikuti pembelajaran konvensional dimana skor hasil belajar IPA kelompok siswa dengan model pembelajaran berbasis masalah lebih besar daripada skor rata hasil belajar IPA siswa dengan model pembelajaran konvensional.

Pengaruh interaktif antara model pembelajaran dan motivasi berprestasi, berdasarkan hasil penghitungan Anakova dua jalan, diperoleh sig. 0,001 , ini berarti $\mathrm{H}_{0}$ ditolak dan $\mathrm{H}_{1}$ diterima, yaitu terdapat pengaruh interaksi antara model pembelajaran dan motivasi berprestasi.

Selanjutnya dilakukan uji Tukey untuk menentukan kelompok siswa mana yang lebih unggul. Hasil uji Tukey menunjukkan bahwa (1) perbandingan 
perbedaan mean antara model PBM pada siswa yang memiliki motivasi berprestasi tinggi dengan model PBM pada siswa dengan motivasi berprestasi rendah sebesar $M=2,50$, dengan model pembelajaran konvensional pada siswa dengan motivasi berprestasi tinggi sebesar $M=0,54$ dan dengan model pembelajaran konvensional pada siswa dengan motivasi berprestasi rendah menunjukkan perbedaan yang sangat signifikan sebesar $M=8,50$, (2) perbandingan perbedaan mean antara model pembelajaran $\mathrm{PBL}$ pada siswa yang memiliki motivasi berprestasi rendah dengan model pembelajaran konvensional pada siswa dengan motivasi berprestasi rendah sebesar $M=6,00$, (3) perbandingan perbedaan mean antara model pembelajaran konvensional pada siswa yang memiliki motivasi berprestasi tinggi dengan model pembelajaran PBL pada siswa dengan motivasi berprestasi rendah $M=1,96$ dan dengan model pembelajaran konvensional pada siswa dengan motivasi berprestasi rendah menunjukkan perbedaan yang sangat signifikan sebesar $M=7,96$.

Berdasarkan data tersebut dapat disimpulkan pada taraf signifikansi 5\% (1) terdapat perbedaan rata-rata hasil belajar IPA antara model pembelajaran PBL pada siswa yang memiliki motivasi berprestasi tinggi dengan model pembelajaran MPK pada siswa dengan motivasi berprestasi rendah, (2) terdapat perbedaan rata-rata hasil belajar IPA antara model pembelajaran PBM pada siswa yang memiliki motivasi berprestasi rendah dengan model pembelajaran MPK pada siswa dengan motivasi berprestasi rendah, (3) terdapat perbedaan rata-rata hasil belajar IPA antara model pembelajaran MPK pada siswa yang memiliki motivasi berprestasi tinggi dengan model pembelajaran MPK pada siswa dengan motivasi berprestasi rendah.

\section{PENUTUP}

Berdasarkan pengujian hipotesis yang telah di paparkan pada bagian-bagian sebelumnya dapat ditemukankan hasil penelitian yang merupakan jawaban terhadap keempat rumusan masalah yang diajukan dalam penelitian ini. Temuantemuan tersebut adalah sebagai berikut (1) setelah perlakuan dikontrol dengan kovariabel hasil belajar awal terdapat perbedaan hasil belajar IPA antara kelompok siswa yang mengikuti pembelajaran berbasis masalah dengan kelompok siswa yang mengikuti model pembelajaran konvensional. Temuan penelitian menunjukkan bahwa secara umum hasil belajar IPA yang mengikuti model pembelajaran berbasis masalah lebih tinggi dibandingkan dengan kelompok siswa yang mengikuti model pembelajaran konvensional, (2) setelah perlakuan dikontrol dengan kovariabel hasil belajar awal terdapat perbedaan hasil belajar IPA yang dicapai oleh kelompok siswa yang memiliki motivasi berprestasi tinggi dengan siswa yang memiliki motivasi berprestasi rendah, (3) setelah perlakuan dikontrol dengan kovariabel hasil belajar awal terdapat pengaruh interaktif antara model pembelajaran dan motivasi berprestasi terhadap hasil belajar IPA.

Berdasarkan pembahasan hasil penelitian menunjukkan bahwa pengaruh model pembelajaran berbasis masalah pada pembelajaran IPA dapat meningkatkan hasil belajar IPA yang lebih tinggi dibandingkan dengan model pembelajaran konvensional. Bagi siswa dengan motivasi berprestasi tinggi, hasil belajar IPA kelompok siswa dengan model pembelajaran Berbasis masalah lebih tinggi daripada pembelajaran konvensional. Sebaliknya bagi siswa dengan motivasi berprestasi rendah, hasil belajar IPA kelompok siswa dengan model pembelajaran berbasis masalah model lebih tinggi daripada model pembelajaran konvensional. Simpulan dalam penelitian adalah model pembelajaran berbasis masalah berpengaruh terhadap hasil belajar IPA siswa ditinjau dari motivasi berprestasi. Untuk memperoleh hasil yang maksimal, dalam pembelajaran perlu memperhatikan dan mempertimbangkan motivasi berprestasi siswa.

$$
\text { Beberapa }
$$

saran yang dikemukakan adalah: (1) dalam proses 
pembelajaran dikelas, khusunya mata pelajaran IPA hendaknya guru menerapkan model pembelajaran berbasis masalah sebagai alternatif dalam pembelajaran IPA. Model ini telah terbukti dan mampu meningkatkan hasil belajar IPA, (2) kepada siswa, hasil penelitian ini dapat menjadi acuan untuk selalu meningkatkan motivasi dalam belajar. Motivasi berprestasi yang tinggi akan mendorong siswa untuk giat belajar, untuk selalu ingin mendapatkan hasil belajar yang lebih baik, (3) penelitain ini dilakukan pada sampel dan materi pembelajaran yang terbatas. Para peneliti lain yang tertarik disarankan untuk melakukan penelitian terhadap sampel yang lebih banyak, tingkat kelas yang beragam, dan materi lain. Jadi, disarankan kepada pihak lain untuk melakukan penelitian sejenis pada pokok bahasan dengan karakteristik yang berbeda atau dengan variabel terikat yang lain untuk mengetahui keefektifan model pembelajaran berbasis masalah.

\section{DAFTAR RUJUKAN}

Ardiliastuti, N. P. A. 2015. Pengaruh model pembelajaran berbasis masalah (problem based learning) terhadap hasil belajar biologi dengan pengendalian keterampilan berpikir kritis siswa SMA. Tesis (Tidak Diterbitkan).

Program

Pascasarjana Universitas

Pendidikan Ganesha Singaraja.

Arikunto, S. 2005. Manajemen penelitian. Jakarta: Rineka Cipta.

Candiasa, I M. 2004. Statistik multivariat dilengkapi aplikasi dengan SPSS. Singaraja: Unit Penerbitan IKIP Negeri Singaraja.

Candiasa, I M. 2010. Statistik Univariat dan Bivariat disertai aplikasi SPSS. Singaraja: Undiksha Press

Inayah, E. R. N. 2013. Motivasi berprestasi dan self regulated learning. Jurnal Online Psikologi. )1(02).
Majid, A. 2013. Strategi pembelajaran. Bandung: Remaja Rosdakarya.

Maslow, A. H. 1970. Motivation and personality. New York: Harper \& Row Publishers.

Nurkancana, W, \& Sunartana, P. 1990. Evaluasi hasil belajar. Surabaya: Usaha Nasional.

Nuryanti, L. 2008. Psikologi anak. Jakarta: PT Indeks.

Permendikbud Nomor 58 Tahun 2014 tentang Kurikulum 2013 Sekolah Menengah Pertama/Madrasah Tsanawiyah. Jakarta: Kemendikbud.

Pradipta, A. W. \& Sofyan, H. 2015. IMPKementasi problem based learning untuk meningkatkan motivasi, kreativitas, dan pemahaman konsep. Jurnal Inovasi Teknologi Pendidikan UNY. 2(1). Tersedia pada http://journal.uny.ac.id. Diakses 12 Maret 2016.

Santyasa, I W. 2012. Pembelajaran Inovatif. Buku Ajar. Universitas Pendidikan Ganesha

Santyasa, I W. 2014. Asesmen dan evaluasi pembelajaran fisika. Singaraja: Graha IImu.

Sugiyono. 2010. Statistika untuk penelitian. Bandung: Alfabeta.

Wiratmaja, C. G. A, Sadia, I W, \& Suastra, I W. 2014. Pengaruh model pembelajaran berbasis masalah terhadap self-efficacy dan emotional intelligence siswa SMS. e- Journal Program Pascasarjana Universitas Pendidikan Ganesha. Tersedia pada http://www. academia.edu. Volume 4. Diakses 25 Maret 2016. 